\title{
Determining Critical Factor in Coffee-to-Go Business Using Analytical Hierarchy Process (AHP): A Case Study in Jakarta Coffee Industry
}

\author{
M. Fauzan, Y. Jerry, N. Allessandro, and S. Aldino
}

\begin{abstract}
Coffee-to-go is a cup of coffee that is brewed at a coffee shop but is taken somewhere else to be consumed. Coffeeto-go business becomes a phenomenon in Indonesia. Abundant coffee-to-go merchants arise with their own characteristics and specialty. Competition in the red ocean market force owner of coffee-to-go business has to obtain competitive advantage among competitors. One solution to lead in the competition provides a suitable business value corresponding to customer wants. This paper discusses critical factors to establish a coffeeto-go business by using Analytical Hierarchy Process (AHP). We conduct this research by having three factors to be analyzed, for instance, menus, service order, marketing, and promotion with its own sub-criteria. Based on this research, the critical factors that customers considered in buying coffee-to-go are consistency with flavor, variation of payment method, and ease of ordering. These factors are important in order to establish a coffee-to-go shop.
\end{abstract}

Index Terms-MCDM, AHP, coffee, critical factor, coffee-togo, Indonesia.

\section{INTRODUCTION}

Coffee is a drink that is served from a coffee green bean. In the process of brewing coffee, the location of the bean, coffee green bean cultivation, roasting method, brewing method, and serving method have an impact on the taste of the coffee drink itself. Murphy, 2017 stated in the research of the coffee value chain, there are three main stages of coffee value chain. Cultivation, Roasting, and Consumption [1] as shown on the Fig. 1.

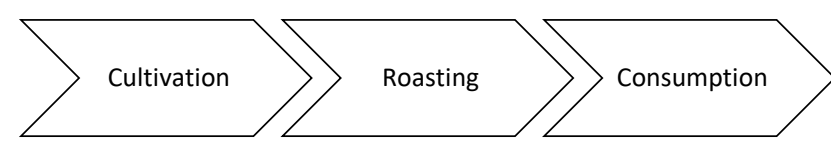

Fig. 1. Coffee value chain.

Coffee as a commodity has already thrived from hobbies to a daily basis consumption. Data in the article that has been released in 2018 by capital claimed that coffee as one of the biggest five commodities that traded in the developing country. Estimated coffee consumers reach 2.25 billion cups in a single day [2].

Jokowi, President of Indonesia, stated in 2019 Skills Festival that the growth of coffee shops and coffee

Manuscript received April 17, 2020; revised June 22, 2020. This work would have been impossible without the support from PT. Bank Central Asia Tbk.

M. Fauzan, Y. Jerry, N. Allessandro, and S. Aldino are with the Industrial Engineering, Universitas Indonesia, Depok, Indonesia (e-mail: Muhammad.fauzan64@ui.ac.id,_Jerry.yudhatama@ui.ac.id, allessandro.nazzario@ui.ac.id, Aldino.syaputra@ui.ac.id). consumption worldwide increased by 20 percent. Given this situation, Indonesia also has been heard throughout the world for the quality of its coffee beans, It ranked 4 th for the biggest coffee exporter in the world for an average of 1.5 billion pounds of grounds each year according to the International Coffee Organization (ICO) which about 7.36 percent of all the exported coffee worldwide. Major markets include the EU, U.S., Malaysia, and Japan [3].

Developing countries that have been mentioned before are Ethiopia, Brazil, Vietnam that famous by its origin beans specialty. Meanwhile, Indonesia has its self-bargaining position in the international coffee market with its famous single-origin beans variety including Arabica and Robusta. In which, Indonesia also famous for its diverse planting location that affects the combination level of acidity, body, scent, and flavor. Currently, there are 17 geographical indications of Indonesian grounds that have been registered, including Arabika Gayo, Robusta Lampung, and Java Preanger.

Coffee in Indonesia itself has also been quite phenomenal, many coffee shops have penetrated Indonesia's food industry competition. Coffee consumption in Indonesia has become one of the activities that shift into a lifestyle in the urban area. Indonesian coffee consumption rate itself has been increasing as the rapid growth of 3rd wave coffee shops in Indonesia. As the Jakartaglobe annual growth rate in the coffee retail market in Indonesia will likely rise by $11.4 \%$ between 2017 and 2021. Making it top of the world's fastest-growing coffee retail market [4].

Greater Area of Jakarta has become one of the growing cities for coffee shop trend. The accessibility of Indonesia's consumer to buy coffee is classified into two channels, which are coffee-to-go and sit-in coffee shop. Both concepts of coffee shops deliver different values to the customer. Coffeeto-go is a cup of coffee that brewed at a coffee shop but is taken somewhere else to be drunk. On the other hand, a sit-in coffee shop is a concept where people tend to stay and experience a cup of coffee in a cafe.

Mintel stated Indonesia was ranked as the world's fastestgrowing consumer of packaged coffee, including instant coffee, ready-to-drink, and coffee in pods or capsules between 2011 and 2016 [4].

This phenomenon is a result of the high enthusiasm of people in Indonesia about coffee. However, with the diversity of single-origin, rapid grow of third-wave coffee shops, bringing a new opportunity to the growing of coffee-to-go, as it could be seen by the number of Coffee-to-go coffee shops concept in the Greater Area of Jakarta, for example Kopi Tuku, Kopi Kulo, Fore, Janji Jiwa, Kopi Kenangan. The total amount of this category is estimated at around 220 outlets in Jakarta [5]. However, data of coffee-to-go did not cover all 
other than the famous brand, there are still many of coffee-togo shop that spreading around Jakarta. The current trend is supported by the cultivating of order trends. In order to grab some food or drink, people nowadays tend to use online delivery or mobile application. Variation delivery method from online channels makes the accessibility much easier.

Competition among coffee shop forces them to improve their performance to get a competitive advantage. Improvement has to be done in areas that critically affects the customer in choosing coffee shops. Newcomers in this industry also have to establish their business correctly which means suitable to the market.

The purpose of this paper is to examine and analyze critical factors that become customer priority in selecting coffee-togo to help people establishing new coffee-to-go business provide values that is suitable with the market by using a multi-criteria dimension method specifically the analytical hierarchy process (AHP).

\section{Methodology}

\section{A. Multi-Criteria Decision Matrix}

This research is conducted in Jakarta in September 2019. This research uses quantitative analysis to analyze the critical factors of consumers' preferences by using Analytical Hierarchy Process (AHP). To examine and analyze the levels of preferences. We used Expert Choice, AHP software for decision assessment.

The Analytical Hierarchy Process (AHP) is one of the MCDM methods that breakdown problems into a system of hierarchies. The result of the AHP matrix is an $m^{*} n$ matrix (where $\mathrm{m}$ is the number of alternatives and $\mathrm{n}$ is the number of criteria). The matrix is constructed by using the relative importance of the alternatives in terms of each criterion [6].

Analytic Hierarchy Process (AHP) is an MCDM method based on priority theory. AHP often used in complex problems that involve the consideration of multiple criteria/alternatives simultaneously. Its ability to incorporate data and judgement of experts into the model in a logical way, to provide a scale for measuring intangibles and method of establishing priorities to deal with interdependence of elements in a system to allow revision of judgements in a short time to monitor the consistency in the decision maker's judgements to accommodate group judgements if the groups cannot reach a natural consensus, makes this method a valuable contribution to the field of MCDM.

The methodology is capable of breaking down a complex, unstructured situation into its component parts, Arranging these parts into a hierarchical order (criteria, sub-criteria, alternatives, etc.) Assigning numerical values from 1 to 9 to subjective judgments on the relative importance of each criterion based on the characteristics synthesizing the judgments to determine the overall priorities of criteria/subcriteria/ alternatives. The eigenvector approach is used to compute the priorities/weights of the criteria/ subcriteria/ alternatives for the given pairwise comparison matrix. In order to fully specify reciprocal and square pairwise comparison matrix, $\mathrm{N}(\mathrm{N}-1) / 2$ pairs of criteria/subcriteria/ alternatives are to shops. The eigenvector corresponding to the maximum eigenvalue $(\lambda \mathrm{MAX})$ is required to be computed to determine the weight vectors of the criteria/ sub-criteria/ alternatives. Small changes in the elements of the pairwise comparison matrix imply a small change in $\lambda \mathrm{MAX}$ and the deviation of $\lambda$ MAX from $N$ is a deviation of consistency. This is represented by the Consistency Index (CI). i.e. ( $\lambda \mathrm{MAX}-$ $\mathrm{N}) /(\mathrm{N}-1)$. Random Index (RI) is the consistency index for a randomly filled matrix of size. Consistency ratio (CR) is the ratio of CI to average RI for the same size matrix. A CR value of 0.1 or less is considered acceptable. Otherwise, an attempt is to be made to improve the consistency in obtaining additional information.

This method is commonly used as a scientific tools to assisting and validating in order making a decision from multiple choices and to confirming critical factor in many topic in order to discover prioritze or critical factor which determined by expert.

\section{B. Geometric Mean}

The geometric mean is a method that calculates the average value with the $n$ root square from all of the values that consist of. The geometric mean is used for data that has weight differences between other data. Geometric mean minimizes extreme values influence. The geometric mean formula is shown below:

$$
G=\sqrt[n]{x_{1} \times X_{2} \times X_{3} \times \ldots \times x_{n}}
$$

Geometric mean is more accurate than the usual average method because for the group response research, false in the geometric mean is smaller than the normal average error. The cut-off point for geometric mean varies.

\section{Data Collection}

Critical factors are indicators that are considered by business owners and control them. Fariddedin et al, 2014 recognized these factors can contribute to the success of an organization and not providing them can increase the probability of organization failure [7]. Critical factors are strongly related to the strategic goal and mission of a business. The factor afterward must be evaluated and derived to several indicators.

Park, 2010 distinguished the attributes of coffee shops from product factors, price factors, diversity factors, environmental factors, accessibility factors, and promotional factors [8]. Research by Kim et al, 2010 stated that coffee flavor as the most important factor in choosing a coffee shop from eight selection attributes; coffee taste, cleanliness and hygiene, location, atmosphere, price, service speed, variety of menu, and brand [9]. AHP model formulation was made by determining the fundamental purpose of this paper, which is defining critical criteria to establish a coffee-to-go business. then we evaluate some factors that affect the success in establishing coffee-to-go followed by criteria and hierarchy of decision-based on the criteria list from various literature. From previously conducted research, all of the coffee shop attributes used in previous research were reclassified according to similarity and relevancy to our topic since there are still a few journals focus on coffee-to-go. We distinguished the selection of critical factors. As a result, there are three factors and seven indicators. The factors and indicators are shown in Table I. Critical Factor. 
TABLE I: CRITICAL FACTOR

\begin{tabular}{|c|c|c|c|c|}
\hline No & Factors & Indicator & Definition & References \\
\hline 1 & \multirow{2}{*}{ Menus } & $\begin{array}{l}\text { Variation of } \\
\text { beverage }\end{array}$ & $\begin{array}{l}\text { The diversity of } \\
\text { beverage products a } \\
\text { coffee shop serves, } \\
\text { either it's a coffee } \\
\text { or non-coffee based }\end{array}$ & $\begin{array}{l}\text { Pozos-brewer, } \\
2015 \text { [15]; } \\
\text { Mendeiros, } 2013\end{array}$ \\
\hline 2 & & $\begin{array}{l}\text { Consistency of } \\
\text { flavor }\end{array}$ & $\begin{array}{l}\text { The uniqueness of } \\
\text { taste, and } \\
\text { consistency of } \\
\text { coffee flavor }\end{array}$ & Lee C, 2019 [16] \\
\hline 3 & $\begin{array}{l}\text { Service } \\
\text { Order }\end{array}$ & $\begin{array}{l}\text { Variation of } \\
\text { payment } \\
\text { method }\end{array}$ & $\begin{array}{l}\text { Alternative of } \\
\text { payment methods } \\
\text { (i.e by cash or } \\
\text { payment gateway) }\end{array}$ & $\begin{array}{l}\text { Dixon Michael et } \\
\text { al, } 2009\end{array}$ \\
\hline No & Factors & Indicator & Definition & References \\
\hline 4 & $\begin{array}{l}\text { Service } \\
\text { Order }\end{array}$ & $\begin{array}{l}\text { Ease of } \\
\text { ordering }\end{array}$ & $\begin{array}{l}\text { The use of the } \\
\text { online platform as } \\
\text { ordering channels }\end{array}$ & $\begin{array}{l}\text { Dixon Michael et } \\
\text { al, } 2009\end{array}$ \\
\hline 5 & \multirow{3}{*}{$\begin{array}{l}\text { Marketing } \\
\& \\
\text { Promotion }\end{array}$} & $\begin{array}{l}\text { Uniqueness of } \\
\text { packaging }\end{array}$ & $\begin{array}{l}\text { Concept, design, } \\
\text { and material used } \\
\text { by a coffee shop for } \\
\text { its menu }\end{array}$ & Zekiri J, 2015 \\
\hline 6 & & $\begin{array}{l}\text { Brand } \\
\text { reputation }\end{array}$ & $\begin{array}{l}\text { The Brand itself } \\
\text { has a good } \\
\text { impression among } \\
\text { people. }\end{array}$ & Chang P, 2012 \\
\hline 7 & & $\begin{array}{l}\text { Promotion } \\
\text { (Discount and } \\
\text { Cashback) }\end{array}$ & $\begin{array}{l}\text { The } \\
\text { competitiveness of } \\
\text { price based on } \\
\text { other's brand } \\
\text { similar product. }\end{array}$ & $\begin{array}{l}\text { Lee J H, } 2014 \\
{[17]}\end{array}$ \\
\hline
\end{tabular}

Medeiros, 2013 finds The "variety of beverage" was another relevant factor in the selection of food services [10]. The coffee shop serves various menu, categorized as coffee and non-coffee based products. Each of the coffee shops has different and unique products that represent the value of the shop. Dixon Michael et al, 2009 findings technology in the restaurant is payment, and ordering system [11]. In most coffee shops, customers could have various payment method selection in order to make a decision on a coffee shop they want to select, the method for example debit card, credit card, traditional payment, or even an e-wallet. According to Thejakartapost, there are around 38 e-wallet apps currently registered in the National Bank of Indonesia (Bank Indonesia) with the total value of transactions was USD 1.5 billion in 2018 [12]. The growing method payment in Indonesia's shopping trend also supported by the easiness of ordering via online delivery that is now conducted by a company that supports the method from an application, for example GrabFood and Go-Food as a marketplace for food and beverages, or even personal apps that managed by specific coffee shop such as Fore, Anomali, and Kopi Kenangan. The packaging is also considered as important factor in customers' buying behavior. Zekiri J, 2015 research on impact of packaging material and design strongly influences customers' decision during buying process [13]. The brand reputation of a coffee-to-go concept strongly can give great impact on the success of the business. Increasing brand reputation means to make a good impression of brand value among people. The previous study conducted by Chang, 2012 resulted in corporate brand reputation is a direct path and is a factor that significantly affects customer satisfaction thus is a direct path and is a factor that significantly affects customer loyalty [14]. Last, the price is also one of the factors that must be addressed.
Price in this term is how a coffee shop offers a discount or cashback of the product they sell. These criteria are needed to be considered to open a coffee-to-go business.

Data was gathered by interviewing and asking the questionnaire from the experts. The questionnaire we used is the AHP form, which uses a 1-9 comparative scale. Table II shows the sample of AHP form that we used to collect data from the expert. Scale 1-9 defines the rate of importance value which shown in Table III. Importance scale.

The coffee shop serves various menu included coffee and non-coffee-based products. Each of the coffee shops has different and unique products that represent the value of the shop. In the most coffee shop, The customers could have various payment method selection in order to make a decision on a coffee shop they want to select, the method could be a debit card, credit card, traditional payment, and e-wallet. The growing method payment in Indonesia's shopping trend also supported by the easiness of ordering via online delivery that is now conducted by a company that supports the method from an application. The packaging is also considered as an important factor in customers' buying behavior, packaging could influence customers' decision making. Not only packaging but also the consistency of its flavor is important to engage with customers' preferences. Brand reputation plays role in customers' impressions on their product. Last, the price is also one of the factors in customers' decision making on buying coffee. These criteria are needed to be considered to open a coffee-shop business, especially on coffee-to-go as customers' decision-making perspective.

TABLE II: AHP FORM

\begin{tabular}{|c|c|c|c|c|c|c|}
\hline \multirow{3}{*}{\begin{tabular}{|l}
\multicolumn{1}{|c}{ Category A } \\
Variation of beverage \\
\end{tabular}} & \multicolumn{2}{|r|}{ Scale } & \multicolumn{3}{|c|}{ Scale } & \multirow{2}{*}{ Category B } \\
\hline & \begin{tabular}{l|l|l}
9 & 8 & 7 \\
\end{tabular} & \begin{tabular}{|l|l|l|l|l|}
6 & 5 & 4 & 3 & 2 \\
\end{tabular} & \begin{tabular}{l|l|}
2 & 3 \\
\end{tabular} & \begin{tabular}{|l|l|l}
44 & 5 & 6 \\
\end{tabular} & \begin{tabular}{l|l|l|l|}
6 & 7 & 8 & 9 \\
\end{tabular} & \\
\hline & $\mathrm{x}$ & & & & & Variation of payment method \\
\hline \multicolumn{7}{|c|}{ TABLE III: IMPORTANCE SCALE } \\
\hline \multicolumn{2}{|c|}{ Intensity of Importance } & \multicolumn{5}{|c|}{ Definition } \\
\hline 1 & & \multicolumn{5}{|c|}{ Equal importance } \\
\hline 3 & & \multicolumn{5}{|c|}{ Somewhat more importance } \\
\hline 5 & & \multicolumn{5}{|c|}{ Much more importance } \\
\hline 7 & & \multicolumn{5}{|c|}{ Very much more importance } \\
\hline 9 & & \multicolumn{5}{|c|}{ Absolutely more importance } \\
\hline $2,4,6,8$ & & \multicolumn{5}{|c|}{ Intermediate values } \\
\hline
\end{tabular}

We define an expert as a coffee consultant or coffee shop owner who runs their business at least 2 years and has a good reputation among the industry as an expert. They have been following the growth of the coffee shop business since the beginning of the third-wave coffee era and have been doing a market overview of recent coffee-to-go phenomena in Jakarta.

\section{DATA PROCESSING}

Since experts who fulfill the questionnaire is more than one, we calculate geomean to obtain the weight of importance. Geomean value determined in Table IV. Geometric Mean. Geomean value is heterogeneous, therefore we round out value that closer to $1-9$ or $1-1 / 9$. We used the weight of importance as an input in pairwise matrix. Thru the pairwise matrix, we can see comparative value among factors. For example, variation of variation of beverages is three times more important than variation of payment method. The weight that we got from the assessment is still in local form, 
which represents importance weight from criteria in the same category. Global weight needed to become weight of the criteria that represent all in order achieving the goal. Global weight obtained from multiple equations of the local weight of category and criteria. Calculation of AHP assisted by Expert Choice software.

TABLE IV: GEOMETRIC MEAN

\begin{tabular}{|l|r|r|r|r|r|l|l|}
\hline \multicolumn{1}{|c|}{ Category 1 } & Expert 1 & Expert 2 & Expert 3 & Expert 4 & Expert 5 & Geomean & Category 2 \\
\hline Variation of beverage & 0.125 & 5 & 7 & 5 & 8 & 2.809361 & Variation of payment method \\
\hline Variation of beverage & 0.166667 & 5 & 0.25 & 7 & 0.142857 & 0.730721 & Ease of ordering \\
\hline Variation of beverage & 8 & 1 & 1 & 7 & 0.111111 & 1.441415 & Uniqueness of packaging \\
\hline Variation of beverage & 0.125 & 0.142857 & 0.111111 & 1 & 0.111111 & 0.185637 & Consistency of flavour \\
\hline Variation of beverage & 0.142857 & 0.142857 & 0.25 & 4 & 0.111111 & 0.295878 & Reputation \\
\hline Variation of beverage & 0.125 & 1 & 1 & 0.333333333 & 0.111111 & 0.341279 & Promotion and Cashback \\
\hline Variation of payment method & 8 & 1 & 1 & 3 & 0.166667 & 1.319508 & Ease of ordering \\
\hline Variation of payment method & 8 & 1 & 0.25 & 3 & 0.111111 & 0.922108 & Uniqueness of packaging \\
\hline Variation of payment method & 0.125 & 0.166667 & 0.111111 & 0.142857143 & 0.111111 & 0.129728 & Consistency of flavour \\
\hline Variation of payment method & 6 & 0.333333 & 0.25 & 0.142857143 & 0.166667 & 0.412234 & Reputation \\
\hline Variation of payment method & 0.125 & 0.25 & 1 & 0.25 & 0.142857 & 0.256767 & Promotion and Cashback \\
\hline Ease of ordering & 6 & 1 & 1 & 2 & 7 & 2.425805 & Uniqueness of packaging \\
\hline Ease of ordering & 0.125 & 0.142857 & 0.111111 & 0.166666667 & 0.111111 & 0.129728 & Consistency of flavour \\
\hline Ease of ordering & 0.142857 & 0.5 & 0.25 & 2 & 0.142857 & 0.347976 & Reputation \\
\hline Ease of ordering & 0.125 & 0.25 & 1 & 2 & 0.125 & 0.378929 & Promotion and Cashback \\
\hline Uniqueness of packaging & 0.125 & 0.333333 & 0.111111 & 0.142857143 & 0.1111111 & 0.149019 & Consistency of flavour \\
\hline Uniqueness of packaging & 0.125 & 1 & 0.333333 & 0.2 & 7 & 0.566478 & Reputation \\
\hline Uniqueness of packaging & 0.166667 & 1 & 2 & 0.2 & 0.142857 & 0.394241 & Promotion and Cashback \\
\hline Consistency of fllavour & 8 & 1 & 9 & 7 & 9 & 5.3868877 & Reputation \\
\hline Consistency of flavour & 8 & 1 & 9 & 7 & 9 & 5.386847 & Promotion and Cashback \\
\hline Reputation & 0.125 & 1 & 3 & 0.2 & 0.142857 & 0.403639 & Promotion and Cashback \\
\hline
\end{tabular}

TABLE V: INCONSISTENCY RATE

\begin{tabular}{|c|c|c|}
\hline \multicolumn{4}{|c|}{ TABLE V: INCONSISTENCY RATE } \\
\hline Matrix & Inconsistency Rate & Result \\
\hline Overall & 0.04 & Consistent \\
\hline Menu & 0.00 & Consistent \\
\hline Service & 0.00 & Consistent \\
\hline $\begin{array}{c}\text { Marketing \& } \\
\text { Promotion }\end{array}$ & 0.01 & Consistent \\
\hline
\end{tabular}

Inconsistency rate must be below $10 \%$. If an inconsistency rate above $10 \%$ researcher has to recollect the data. Based on TABLE V: Inconsistency Rate, all of the matrix is has inconsistency rate below $10 \%$, which means the data is consistent and valid.

\section{RESUlt AND DisCUSSION}

\section{A. Result}

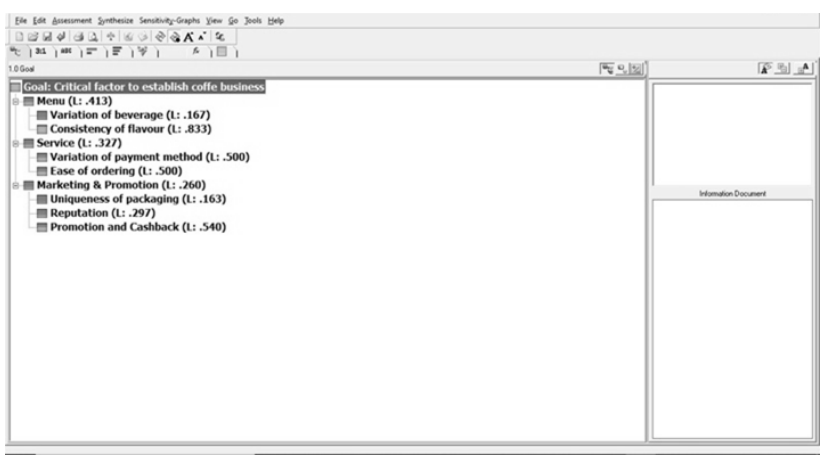

Fig. 2. Result of the assessment on the software

Based on pairwise comparison and AHP data synthesis using expert choice we can assume consistency of flavor, variation of payment method, and ease of ordering become critical factor in establishing coffee to go business, whereas promotion, brand reputation, variation of beverage, and uniqueness of packaging are not that critical to making coffee-to-go business become success. The inconsistency rate is 0.04 which means the assessment is valid. Fig. 2 and Fig. 3 shows the data processing using software.

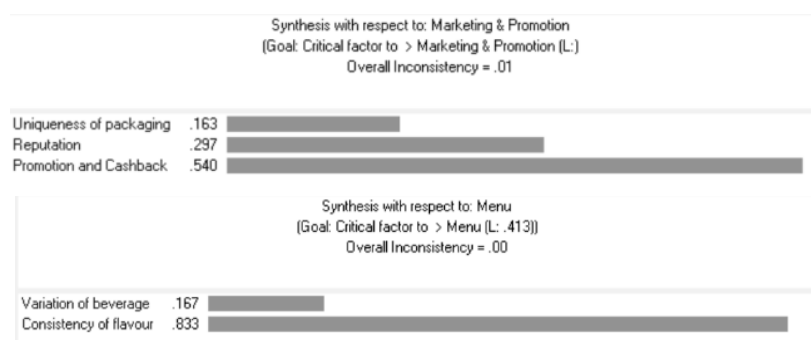

Fig. 3. Consistency rate of variable in category.

\section{B. Discussion}

From the pairwise comparison result, we can conclude that the "Consistency of flavor" is the most critical factor to establish a coffee-to-go business. Experts see that every coffee shop must concern about this factor as the uniqueness and the consistency of coffee beans flavor become a competitive advantage for the business. For example, what kind of house blend they use, what is their recipe to make their coffee-based menu, are one of the things to be concerned at the early stage before they started the business of coffeeto-go. Followed by "Variation of payment method" and "Ease of ordering". The variation of payment method tends to make people easier to choose what kind of payment method they would like to use. People tend to save their money over many payment getaways brand, for instance, OVO, Gopay, Dana gain attention among people. Recently, people depend on any kind of food ordering services to assist their life in order of buying food and beverages. Most of coffee merchants collaborate with varies food ordering service, for instance, Go-food or Grab food as two of big players in that kind of service.

Some experts stated that the people who drink coffee are divided into four segments, follower, drinker, connoisseur, and enthusiast. Each of these segments has its own unique characteristics. People who drink coffee have been shifting their way of drinking coffee. Coffee-to-go can mediate behaviour of people to change their way of drinking coffee. The rapid growth of Coffee-to-go could disturb the business of coffee sachet. People can get better quality of coffee by small switching costs. However, Coffee-to-go and sit-incoffee create a mutual benefit among each other. As the similarities of customer segment between those two. It is a challenge for the coffee business to keep their quality of coffee taste so that customers could still felt the same taste experience as in sit-in method of drinking coffee.

There is a prospect for venture capital to penetrate further into the coffee-to-go business with the view of clearer assets and valuation. Coffee-to-go business owners can imitate the business model of Fore coffee and Kopi Kenangan that already obtain USD 8.5 Million [18] and USD 28 Million [19] investment respectively. Experts believe that coffee-to-go business still prospecting until more than ten years.

\section{CONCLUSION}

Coffee to go become quite a phenomenon in Indonesia's business, especially in Jakarta. The impact of that phenomenon is the rise of coffee-to-go merchants that escalated quickly. The trend of coffee to go predicted still remains for more than 10 years. That condition makes the 
coffee-to-go business become a promising business. To establish proper coffee to go business. A business owner has to consider with the value which suits the customers' needs to avoid value surplus or absence in the business. It has been calculated with AHP method with an inconsistency rate of 0.04 which is considered as valid assessment that the values customers concern the most are consistency with flavor, variation of payment method, and ease of ordering. That value is most important factor for customers to choose variant of coffee to go. There is still another value that can't be ignored by a business owners to establish the coffee-to-go business. A business owners also can consider new form of funding which was done by Fore coffee and Kopi Kenangan who treat their coffee shop similar to the initial public offering company.

\section{CONFLICT OF INTEREST}

The authors declare no conflict of interest.

\section{AUTHOR CONTRIBUTIONS}

All of the author is involved in this research, we interviewed the expert and wrote this paper. However, N. Allessandro focus on the data processing; M. Fauzan focus on analyzed the data; S. Aldino and Y. Jerry focus on searching the experts; all authors had approved the final version.

\section{ACKNOWLEDGMENT}

Our thanks to expertise who provided insight and their assistance in this research.

\section{REFERENCES}

[1] M. Murphy and T. Dowding. (2017). The coffee bean: A Value Chain and sustainability initiatives analysis. [Online]. pp. 1-19. Available: http://global.business.uconn.edu/wp-content/uploads/sites/1931/2017 /01/The-Coffee-Bean.pdf

[2] A. Pankratyeva. (2018). Top 5 most traded commodities in the world. Capital.com. [Online]. Available: https://capital.com/top-5-mosttraded-commodities-in-the-world

[3] ICO. (2017). ICO Annual Review: [Online]. 50. Available: http://www.ico.org/documents/cy2017-18/annual-review-websitee.pdf

[4] Adinda Normala. (2018). Indonesia's coffee retail market shows lots of promise: Study. [Online]. Available: https://jakartaglobe.id/context/indonesias-coffee-retail-market-showslots-of-promise-study/

[5] N. Hamid. (2019). Best 'es kopi' chains in Jakarta: Where to find cafes, shops and stalls serving Indonesia's beloved iced coffee concoction. coconuts.co. [Online]. Available: https://coconuts.co/jakarta/fooddrink/best-es-kopi-chains-in-jakarta-where-to-find-cafes-shops-andstalls-serving-indonesias-beloved-iced-coffee-concoction/
[6] H. Polatidis, D. A. Haralambopoulos, G. Munda, and R. Vreeker, "Selecting an appropriate multi-criteria decision analysis technique for renewable energy planning," Energy Sources, Part B: Economics, Planning and Policy, vol. 1, no. 2, pp. 181-193, 2006.

[7] F. A. Haery, H. Ghorbani, and A. A. Farahmand, "An AHP approach for ranking critical success factors of customers experience in Iranian banks from managers' viewpoint," International Journal of Marketing Studies, vol. 6, no. 1, pp. 168-176, 2014.

[8] K. Park, "A study of college students' actual conditions of using coffee shops and choice attributes - focused on seongnam area," The Korean Journal of Food and Nutrition, vol. 23, no. 1, pp. 52-62, 2010.

[9] K. Kim, "A perceptual mapping of coffee shop brands and preference attributes," Culinary Science \& Hospitality Research, vol. 16, no. 3, pp. 66-75, 2010.

[10] C. O. Medeiros and E. Salay, "Food service industry, restaurant, consumer; food service industry, restaurant, consumer," Food and Public Health, vol. 2013, no. 4, pp. 176-190, 2013.

[11] M. Dixon, S. E. Kimes, and R. Verma, "Customer preferences for restaurant technology innovations," Cornell Hospitality Report, vol. 9 , no. 7, pp. 6-16, 2009.

[12] The top five e-wallet apps in Indonesia. (2019). [Online]. Available: https://www.thejakartapost.com/life/2019/08/14/the-top-five-e-walletapps-in-indonesia.html

[13] J. Zekiri, "The role and impact of the packaging effect on consumer buying behaviour," Ecoforum, vol. 4, no. 1, pp. 232-240, 2015.

[14] H.-C. Chang, Y.-T. Tu, and C.-M. Wang, "Corporate brand image and customer satisfaction on loyalty: An empirical study of starbucks coffee in Taiwan," Journal of Social and Development Sciences, vol. 3 , no. 1, pp. 24-32, 2012

[15] R. Pozos-Brewer, "Coffee shops : Exploring urban sociability and social class in the intersection of public and private space rose pozosbrewer sociology," Thesis, May 2015.

[16] C. S. Lee, "A comparative study for selection attributes of coffee shop using AHP," International Journal of Innovative Technology and Exploring Engineering, vol. 8, no. 8, pp. 993-996, 2019.

[17] J. H. Lee, "The effect of the selection attributes of coffee shops on customer value and revisit intention - Focusing on college students in Busan," Culinary Science \& Hospitality Research, vol. 20, no. 3, pp. 171-185, 2014.

[18] N. Atifi. (2019). Indonesia O2O coffee startup bags $\$ 8.5 \mathrm{~m}$ from east ventures, others. techinasia.com. [Online]. Available: https://www.techinasia.com/fore-coffee-85m-indonesia

[19] Jon Russel. (2019). Indonesia’s kopi kenangan raises a Sweet \$20M to expand its coffee business. Techinasia.com. [Online]. Available: https://techcrunch.com/2019/06/25/kopi-kenangan-raises-20-million/

Copyright (C) 2020 by the authors. This is an open access article distributed under the Creative Commons Attribution License which permits unrestricted use, distribution, and reproduction in any medium, provided the original work is properly cited (CC BY 4.0).

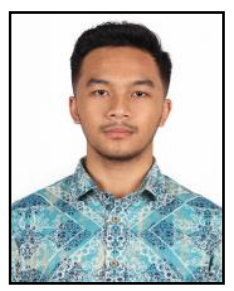

Muhammad Fauzan was born on April $15^{\text {th }} 1999$ in Jakarta. He received a Bachelor Degree in Industrial Engineering from University of Indonesia. His Interest is on supply chain management, production process, manufacturing, and decision support. He was an Laboratory Assistant at Manufacturing and System Lab University of Indonesia. He was an intern for Chevron Pacific Indonesia and PT. Mass Rapid Transportation Jakarta (MRTJ) 